\title{
AGRICULTURAL POLICY: ITS EFFECTS ON NATURE, AGRICULTURE AND THE LAND IN SASKATCHEWAN
}

\section{INTRODUCTION}

KEN PIVNICK, SNHS Endangered Species and Spaces Committee, 209 7th Street East, Saskatoon, Saskatchewan. S7H OW9 and FRED THORNTON, JOCE BOWMAN, and DAVID STRUTHERS, Western Resource Management Associates Limited, Box 4-B Site 2, Yorkton, Saskatchewan.

Historically, people working in agriculture and those involved with the preservation of flora and fauna and their natural habitats have often viewed the landscape of Saskatchewan from conflicting perspectives. Recently, however, members of both groups have started to recognize that their respective aspirations for the land have enough in common that for either group to achieve its goals, both must achieve them. This has resulted from a realization that certain indicators within Saskatchewan's agricultural landscape, reflecting its overall health, are in decline. These include: the productivity of the land; water quality and quantity; the number of farms and rural communities; the quality of rural life; and the diversity and abundance of natural habitats. Indicators that are increasing include: the amount of cultivated land; the frequency of farm bankruptcy; the stress of rural life; the number of children of farm families that are permanently leaving the farm; the number of threatened or endangered species; and the number of undesirable, introduced species.
Society has failed to recognize the relationship between a healthy ecosystem and the agricultural viability we need to support ourselves. All people, from urban dwellers to prairie farmers, need to understand the ecological relationship between natural landscapes, abundant wildlife, fertile soil, water quality, excellent crops, stable income, ecosystem viability, and human well-being.

Several recent Canadian government studies have identified some of the major problems and the policies behind them. ${ }^{1,2}$ They point out that modern agriculture is primarily concerned with short-term profit in a global economic arena over which individual producers have little or no control. Environmentally sensitive agricultural practices are perceived as profitable only in the long-term and this attitude hinders their adoption. Government policies exacerbate the situation by continuing to encourage traditional objectives, such as maximization of cultivated acres, despite the attendant problems of soil erosion, declining soil organic content, and loss of habitat. 
These studies generally recommend that all sectors of the Canadian economy be educated on the interrelationship between the environment, natural resource sustainability (including agriculture), and economics. They promote the creation of committees and advisory boards to help integrate economic and environmental goals in policy and practice. In addition, the studies recommend continuing research and extension into: the reduction of soil erosion; reduced reliance on nonrenewable energy, inorganic fertilizers and pesticides through more sophisticated technology; and intensified monitoring of environmental indicators. While these studies address the obvious problems, they do not deal with the root causes and consequently the public is allowed to believe that the problems can be solved without any fundamental changes in our life style and society's infrastructure. As one example, our society considers the economy unhealthy if it is not growing substantially. Yet our economy must soon begin to shrink; certainly it cannot grow indefinitely as its sustainable size is largely a function of the productivity and health of our environment.

The Saskatchewan Natural History Society (SNHS) Endangered Species and Spaces Committee is examining four federal and Saskatchewan government policies that relate directly to prairie agriculture: the Gross Revenue Insurance Plan (GRIP), the Canadian Wheat Board quota system, Saskatchewan rural municipal assessment and taxation policy and southern Saskatchewan crown land policy. In a series of articles in Blue Jay, these policies will be examined from a "holistic" perspective, defined by the fundamental measures of biodiversity, environmental sustainability and agricultural suitability. The maintenance of a landscape that includes endangered native prairie species and their habitats can only be successfully accomplished with integration into the broader context of agriculture and human society.

The purpose of this initiative is threefold. First, we hope to educate the SNHS membership with regard to present Saskatchewan land management policy and related issues. Second, we will point out some of the important interconnections between agriculture, policy, and the land and all its inhabitants. Third, we hope to provide tools to the membership to look beyond present land use practices and related policy to develop the public awareness, public pressure and the creativity necessary to develop and demand land use policy and practices which are healthy and sustainable.

1. GIRT, J. 1990. Common ground: recommendations for policy reform to integrate wildlife habitat, environmental, and agricultural objectives on the farm. Wildlife Habitat Cai ada. 56 pp.

2. LEBLOND, G. 1990. Growing together. Report to the Federal-Provincial Agricultural Committee on Environmental Sustainability. $41 \mathrm{pp}$. 